DAE Working Paper 0118

\title{
The Restructuring and Privatisation of British Rail: Was it really that bad?
}

\author{
MICHAEL G. POLLITT \\ Judge Institute of Management, University of Cambridge \\ ANDREW S. J. SMITH \\ Judge Institute of Management, University of Cambridge
}

November 2001

\begin{abstract}
Following the government's decision to place Railtrack into administration (October 2001), attention has focused on what went wrong with privatisation, and how crucial network investment will be financed in future. This paper uses a social cost-benefit analysis framework to assess whether the restructuring and privatisation of British Rail has produced savings in operating costs. The paper shows that major efficiencies have been achieved, consumers have benefited through lower prices, whilst the increased government subsidy has been largely recouped through privatisation proceeds. We find that output quality has also improved (pre-Hatfield). The achievement of further savings will be key to delivering improved rail services in the future. This paper finds that a privatised structure, where shareholders demand a return on their investment, has led to significant improvements in operating efficiency - it remains to be seen whether the new regime, with a not-for-profit infrastructure owner, will deliver the same efficiency improvements.
\end{abstract}

JEL classification: H43, L92.

Key words: Cost benefit analysis; railway; privatisation and restructuring; efficiency. 


\title{
The Restructuring and Privatisation of British Rail: Was it really that bad?
}

\author{
MICHAEL G. POLLITT \\ Judge Institute of Management, University of Cambridge \\ email: m.pollitt@jims.cam.ac.uk \\ ANDREW S. J. SMITH* \\ Judge Institute of Management, University of Cambridge \\ email: a.smith@jims.cam.ac.uk
}

November 2001

\section{I: Introduction}

Over the period 1994-1997 the British railway industry was fundamentally transformed. In 1994 the industry was in the hands of a single, vertically-integrated operator - British Rail - owned by the government. By 1997, BR's activities had been transferred to the private sector. In the process, the industry was restructured into more than one hundred companies, thereby removing much of the vertical and horizontal integration of the preprivatisation structure.

Since its reoganisation, and subsequent transfer to the private sector, the rail industry's outputs have grown sharply. Between 1992/93 (the last year before restructuring began $^{1}$ ) and 1999/00, passenger miles and freight tonne-miles grew by $21 \%$ and $19 \%$ respectively, whilst train miles were also up significantly (passenger train miles grew by $13 \%$ over the period). During this same period, total industry costs ${ }^{2}$ fell by nearly $6 \%$, suggesting that significant efficiency improvements have been made.

However, the privatisation of British Rail has been the subject of much criticism in recent years, particularly in the aftermath of the Hatfield disaster. In October 2001 the

\footnotetext{
* Pollitt and Smith are both at the Judge Institute of Management Studies, University of Cambridge. Smith is funded by the Railtrack Studentship in Rail Regulation. The authors wish to thank Luisa Affuso for kindly sharing data with us (data which was generated during a rail research project sponsored by the ESRC - grant number: R000237928). The authors also acknowledge comments from David Newbery, Luisa Affuso and Stephen Gibson. Usual caveats apply.

${ }^{1}$ See Section III.2 (a).

${ }^{2}$ Operating costs (excluding depreciation).
} 
Government announced that it had decided to put Railtrack into administration - with the company to be replaced by a not-for-profit company, limited by guarantee. Railtrack's finances had been crippled by the cost of Hatfield, and cost over-runs on the West Coast Main Line project.

In the aftermath of the government's announcement, attention has focused on what went wrong with privatisation, and how crucial investment for maintenance and development of the network will be financed in future. This paper looks at whether the restructuring and privatisation of British Rail has produced savings in operating costs, relative to the counterfactual scenario of continued public ownership. Operating costs include train operator costs (train crews; traction costs; maintenance and cleaning of rolling stock), the cost of operating the rail network (including signal operators), and dayto-day track maintenance and inspections. The analysis excludes all capital (or depreciation) costs, and therefore excludes the cost of track (and other infrastructure) repairs and renewals, and the capital cost of rolling stock.

The paper uses the technique of social cost-benefit analysis (SCBA) - as developed by Jones, Tandon and Vogelsang (1990) - to evaluate the operating efficiency gains (or losses) resulting from privatisation, and also considers the allocation of these gains (or losses) between consumers, producers and government. The analysis assumes the growth in outputs achieved in recent years to be exogenous, and therefore focuses on the cost of delivering these outputs under the alternative scenarios of private and public ownership. The paper also looks at the changes in output quality (performance; overcrowding; asset condition; safety) since privatisation.

The analysis uses data for the period to 1999/00 (financial year) only, and therefore does not take account of the effects of Hatfield. The next financial year (2000/01), which includes the Hatfield disaster, is not representative of the period since privatisation as a whole (and not all of the financial data are available in any case). Indeed, the effects of Hatfield continued into the financial year 2001/02. The analysis should be updated once data become fully available for three further years (2000/01, 2001/02 and 2002/03).

It should be noted that the change in industry structure means that it is not straightforward to compare railway costs before and after privatisation. Our analysis makes a number of adjustments to the data to ensure comparability. Inevitably a number of assumptions have also been made. These adjustments and assumptions are explained in the relevant section of the paper (and also in the appendices).

The SCBA methodology has previously been applied to a number of privatised industries in the UK, for example, electricity (Domah and Pollitt, 2001), and some of the earlier sell-offs (Galal et al, 1994; Martin and Parker, 1997). The paper is arranged into five sections. Section II briefly outlines the historical background. Section III summarises the theoretical arguments for liberalisation (restructuring and privatisation), and sets out 
the SCBA methodology and data used. Section IV shows the results of the analysis, and Section V offers some conclusions.

\section{Historical background}

The railway network in Britain was planned, financed and built by the private sector in the $19^{\text {th }}$ Century. The industry was nationalised in 1948 , and then returned to private ownership during the period 1995-1997, as part of the wider programme of sell-offs carried out by four successive Conservative administrations (1979-1997).

Since nationalisation, rail traffic has been in almost continual decline in the face of increased competition from road transport (see Figures 1A and 1B). In the early 1950s, passenger rail travel accounted for roughly $17 \%$ of total passenger traffic - by the mid1990s this share had fallen to around 5\%. Rail freight business saw an even sharper loss of market share, from over $40 \%$ to just $7 \%$ over the same period, driven by the loss of traffic to roads, and the decline of Britain's heavy manufacturing and primary industries (which rail freight was particularly well placed to serve). Rail volumes also fell in absolute terms up until the mid 1990s. As noted in the introduction, these trends have been reversed since privatisation ${ }^{3}$.

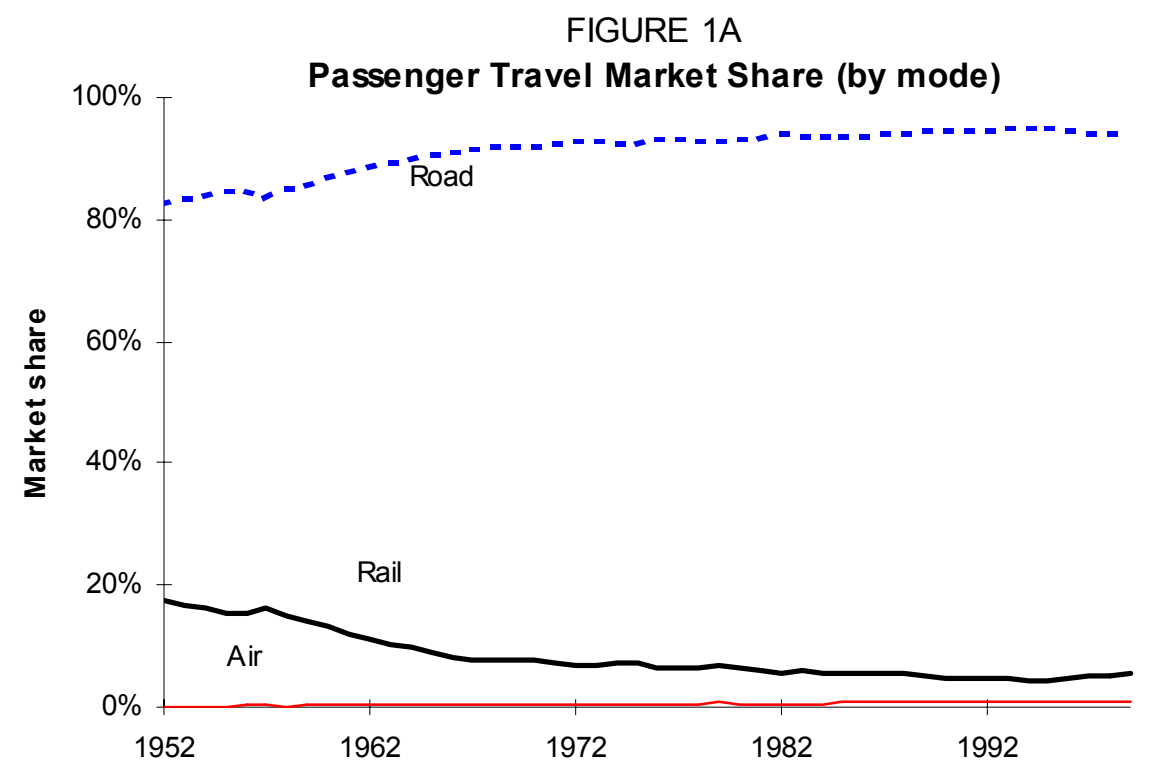

\footnotetext{
${ }^{3}$ The upturn in the rail volumes began in 1995/96, one year before the industry had been fully privatised.
} 


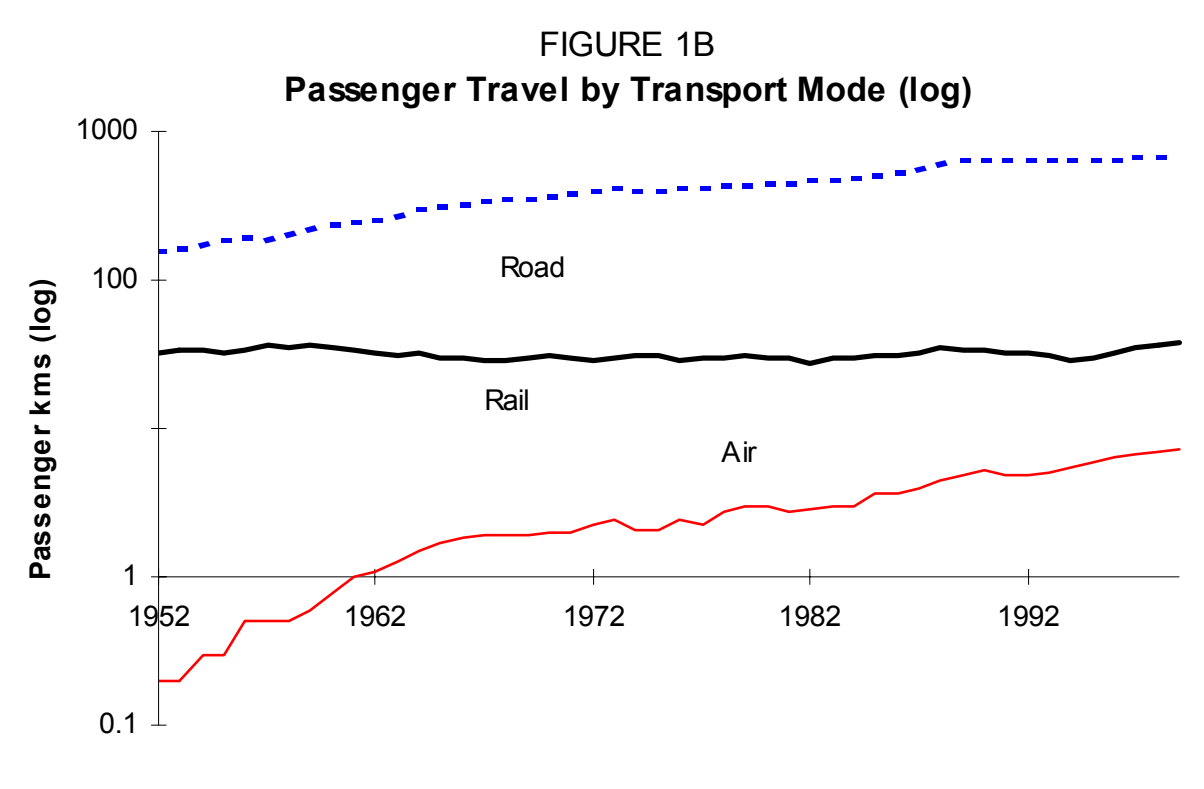

Sources: Transport Trends, 2001 Edition (DTLR).

The railways moved into a loss-making position in the mid-1950s and, in spite of the line and station closures implemented following the Beeching reports $(1963 ; 1965)$ which saw the total route mileage reduced by a third - the industry's financial position continued to deteriorate during the 1970s and early 1980s (as productivity growth slowed whilst wages were on the increase; and as government controls prevented the development of commercial pricing). The 1968 Transport Act explicitly recognised the need for government subsidy to support loss-making (but socially-beneficial) services. However, in line with worsening performance, the level of subsidy also increased over time, reaching $£ 1$.6bn by $1985 / 86$, compared to $£ 600 \mathrm{~m}$ in 1968 (1999/00 prices).

During the 1980s it was recognised that the financial position of the industry, and the requirement for government support, would complicate any attempt at privatising the industry. Rail privatisation would require route closures and/or continued government subsidy after sale. As a result, proposals for rail privatisation developed slowly during the 1980s, finally culminating in the sale of the industry during the period 1995-1997.

However, the government (and BR), were not idle in the meantime, and began selling off many of BR's non-core operations (see Table 1). Some of these sales raised substantial sums (for example, BR Hotels raised $£ 150 \mathrm{~m}$ in 1999/00 prices) ${ }^{4}$.

\footnotetext{
${ }^{4}$ Source: Public Enterprise Partnerships Team, HM Treasury.
} 
TABLE 1

BR Non-core Businesses Sold to the Private Sector (1981-1993)

\begin{tabular}{l|l}
\hline BR Hovercraft (1981) & Doncaster Wagon Works (1987) \\
BR Hotels (1982-1984) & Horwich Foundry (1988) \\
Superbreak Mini Holidays (1983) & British Rail Engineering Ltd (1988) \\
Slateford Laundry (1983) & $\begin{array}{l}\text { Travellers Fare [station catering] } \\
(1988)\end{array}$ \\
Sealink UK (1984) & Transmark [consultancy] (1993) \\
British Transport Advertising (1987) & Meldon Quarry (1993) \\
\hline
\end{tabular}

Sources: Bradshaw and Lawton-Smith (p 104) and Freeman \& Shaw (page 9).

The debate on privatising the core railway operations continued throughout the $1980 \mathrm{~s}$ and early 1990s. In 1992, immediately following the surprise Conservative election victory, a White Paper, 'New Opportunities for the Railways' (Department of Transport), was quickly put together under the direction of the John MacGregor (then Secretary of State for Transport). The strong likelihood that the Conservatives would lose the subsequent election (1997) injected an urgency into the process, as the government sought to complete the sale of the industry in one Parliament - and thus make privatisation effectively irreversible.

The 1992 White Paper outlined the government's privatisation objectives, which were similar to those for previous sell-offs: to harness the skills of private sector management, in order to achieve greater responsiveness to customer needs, higher service quality, improved efficiency and better value for money. The introduction of competition was thought to be the best way of achieving these objectives (following the example of the electricity restructuring in 1990), although it was recognised that regulation would be required to protect consumers (especially with regard to safety).

As a result, the industry was separated (vertically and horizontally) into more than one hundred companies (see Figure 2 below), to allow competition to develop in the contestable elements of the business. The restructuring was carried out initially within the public sector, creating shadow companies, which were later sold.

The most significant change was the separation of control of the track infrastructure (natural monopoly) from train operation (contestable). In 1994, most of the fixed railway infrastructure assets were transferred to a new company, Railtrack, separate from BR, but still wholly-owned by Government. The company was sold by public offer in $1996^{5}$.

At the same time, BR's infrastructure services were reorganised into seven infrastructure maintenance and six track renewal companies (sold between February and July 1996). BR's rolling stock was divided into three leasing companies (ROSCOs). The ROSCOs (sold in January/February 1996) lease locomotives and carriages to the

\footnotetext{
${ }^{5}$ See Kain (1998) page 248; NAO Report (HC 25 Session 1998-99) page 20.
} 
passenger train operating companies ${ }^{6}$. Six heavy maintenance depots (provide services to ROSCOs) were also sold in April and June $1995^{7}$.

The right to run passenger train services was franchised to 25 private sector train operating companies (TOCs) - with open-access competition to be introduced gradually under the "moderation of competition" rules laid down by the Regulator (from 1995 onwards). TOCs lease almost all of their rolling stock from the ROSCOs, and pay Railtrack for access to track and stations. Red Star Parcels was sold to a management buy-out in September $1995^{8}$.

FIGURE 2

The New Rail Industry in 1996/97

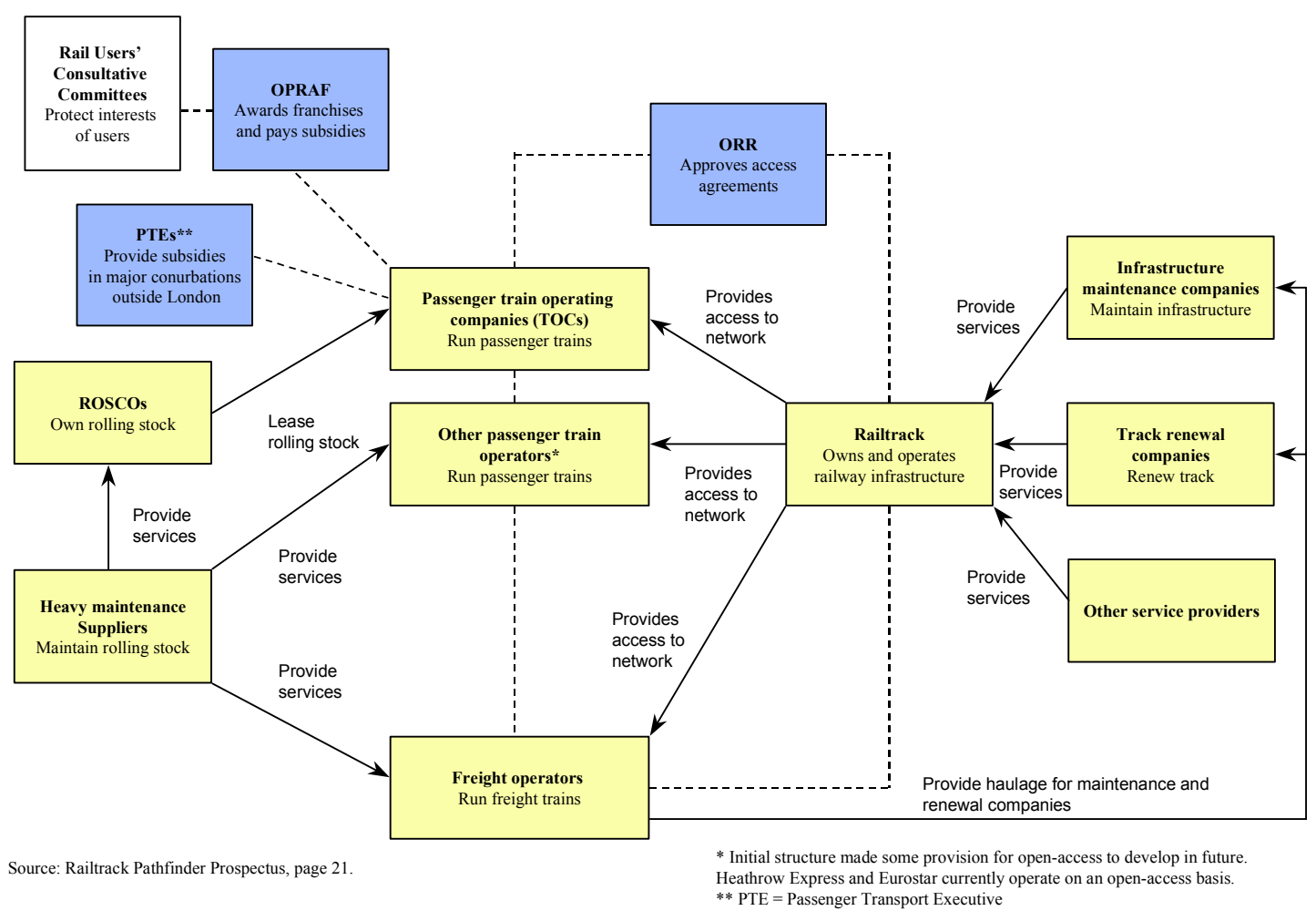

Freight operations were separated into six companies (later consolidated into two) and sold between December 1995 and November 1997 (with open-access competition

\footnotetext{
${ }^{6}$ See NAO (HC 576 Session 1997-98) p 1.

${ }^{7}$ See NAO (HC 25 Session 1998-99) page 22.

${ }^{8}$ Provides rapid parcels distribution on passenger trains - see, Department of Transport, 'New Opportunities for the Railways' page 12; British Railway Board Accounts 1995/96.
} 
allowed from the outset). In addition, many other BR central services operations were sold to private sector companies or management teams ${ }^{9}$.

As part of the reorganisation, two regulatory bodies were also created: (1) The Office of Rail Regulator (ORR), principally to regulate the monopoly element of the business Railtrack; and (2) The Office of Passenger Rail Franchising (OPRAF), mainly responsible for awarding franchises, paying subsidies, and regulating the $\mathrm{TOCs}^{10}$. Rail Users' Consultative Committees (RUCCs) were established to work with OPRAF in protecting the interests of rail users ${ }^{11}$. Safety regulation was placed with the Health $\&$ Safety Executive.

Having described the background to rail privatisation, the remainder of the paper concentrates on whether the new structure has met one of the government's main objectives - namely, improving operating efficiency - and how any efficiency gains (or losses) have been allocated between consumers, producers and government.

Since privatisation industry outputs have increased substantially (reversing a longterm trend of decline), whilst costs have fallen in real terms. The new structure gave the TOCs strong incentives to increase outputs and reduce costs (because of declining subsidies; fixed access charges). Whilst part of the output growth since the mid 1990s can be attributed to privatisation itself - through, for example, fare regulation and better marketing) - in the subsequent analysis (Section IV) we make the conservative assumption that output growth has been driven entirely by exogenous factors (eg. GDP growth; road congestion). This assumption reduces the benefits attributed to privatisation in our analysis.

Our analysis therefore focuses on whether the industry's outputs - driven by exogenous factors - would have been delivered more cheaply under the new structure than under continued public ownership. Data on output quality (performance; overcrowding; asset condition; safety) are also evaluated. The new structure contained a number of features to ensure that efficiency gains would be shared with consumers (fare regulation; competition) and government (declining subsidy profile). The analysis in Section IV quantifies the allocation of efficiency gains (or losses) between the different groups.

\footnotetext{
${ }^{9}$ See Kain (1998), page 250; Bradshaw and Lawton-Smith (2000), pages 108; 118; NAO Report 'The Sale of Railfreight Distribution'.

${ }^{10}$ John Swift (QC) and Roger Salmon were appointed as the first Rail Regulator and Franchising Director respectively (January 1993) - see Freeman \& Shaw (2000), page 207.

${ }^{11}$ See Freeman \& Shaw (2000), p 33.
} 


\section{Methodology}

\section{Theoretical issues and empirical work}

The ideological belief underlying the privatisation of British Rail was that the injection of private sector expertise and flair would result in improved services, more efficient operations, and better value for money for the traveling public. It was also hoped that the private sector would be able to lure passengers and freight customers back to the railways (greater responsiveness to customer needs), and arrest the long-term decline of the industry.

However, following earlier privatisations (eg. BT and British Gas), it was recognised that change in ownership alone would be insufficient to deliver the required improvements in services and cost. Whilst private ownership and the profit motive provide better incentives than public ownership, the government saw competition, and the ending of BR's monopoly, as key to delivering improvements on the railways.

The liberalisation of public enterprises in general often involves three separate, and not necessarily connected elements: changes in ownership; the creation of new, or radically restructured companies; and the introduction of some degree of competition. Depending on the combination of these factors, liberalisation will tend to cause significant changes in the way businesses are conducted. Pollitt (1997) identifies five theoretical arguments relating to the likely efficiency effects of liberalisation:

1. liberalisation can improve incentives by reallocating property rights from the public to the private sector;

2. liberalisation may change the objective functions of managers being faced with private sector incentives for the first time;

3. there may be incentives for distortionary resource allocation, caused by some types of regulation (eg. rate of return regulation) leading to inefficiency;

4. liberalisation may cause "influence activities" within the industry (eg. empire building), which may result in a divergence from efficiency; and

5. policy commitment theories suggest that liberalisation will result in lower intervention costs.

Pollitt (1997) notes that, in a developed, market economy such as the UK, the theoretical predictions provide some (weak) support for restructuring and privatisation in 
the case of property rights, bureaucracy and commitment theories; but that poorly constructed incentive regulation could negate all the other positive benefits from liberalisation. As a result, the impact of any particular restructuring and privatisation process (in a given industry or country) has the potential to be highly variable.

A number of methodologies have been used to assess the impact of liberalisation, for example based on price or cost comparisons, as used by Yarrow (1992) and Bishop and Thompson (1992), or using simulation or frontier approaches, such as Burns and Weyman-Jones (1994). These methodologies have been criticised as they do not directly address the issue of whether it is likely to be socially beneficial (in particular they do not address the distributional effects of liberalisation).

A more comprehensive approach would be the computational general equilibrium (CGE) method (for example, Chisari, Estache and Romero,1999), which assess the macroeconomic and distributional effects of privatisation and regulation. However, none of these approaches possess the power of an overall social cost-benefit analysis (outlined below), and are themselves based on numerous assumptions regarding specification of objectives and constraints.

SCBA studies, for example Galal et al (1994) and others (Newberry and Pollitt, 1997) have addressed the failures of the other methodologies. In this paper we use a SCBA framework to analyse the effect of liberalising Britain's railway industry.

\section{The Social Cost-Benefit Methodology}

The methodology developed by Jones, Tandon and Vogelsang is concerned first with assessing the total change in welfare resulting from privatisation and restructuring, and second with the allocation of this change, principally between three groups, consumers, producers (ie shareholders of the new, privatised companies), and government ${ }^{12}$. The first question relates to the productive efficiency impact (net of restructuring costs) of liberalisation, whilst the latter is concerned with equity. For simplicity our analysis ignores changes in allocative efficiency.

Jones et al define the privatisation decision according to the following formula:

$\alpha ́ \mathrm{~W}=\mathrm{V}_{\mathrm{sp}}-\mathrm{V}_{\mathrm{sg}}+\left(\square_{\mathrm{g}}-\square_{\mathrm{p}}\right) * \mathrm{Z}$

where: $\mathrm{W}=$ Social Welfare; $\mathrm{V}_{\mathrm{sp}}=$ Social value of firm under private operation; $\mathrm{V}_{\mathrm{sg}}=$ Social value of firm under continued government operation; $\mathrm{Z}=$ Price paid to buy

\footnotetext{
${ }^{12}$ Jones et al also consider other parties, such as competitors and suppliers (often excluded from empirical applications of the methodology on practical grounds), and workers (often excluded on the grounds that any rents earned by employees are fully compensated through redundancy payments, which are included within the cost base of the companies concerned).
} 
the firm (or government sales proceeds) and $\square_{\mathrm{g}}$ and $\square_{\mathrm{p}}$ are the shadow multipliers on government revenue and private funds respectively.

Privatisation will be socially worthwhile if á $\mathrm{W}>0$. In a developed, market economy, we would expect no significant difference in the value of shadow multipliers, so for the purpose of our analysis we set $\square_{\mathrm{g}}=\square_{\mathrm{p}}=1$. The sales proceeds variable, $Z$, which is a transfer payment between government and producers, therefore drops out of the equation (though remains important for its distributional effects).

The calculation of $\alpha \mathrm{W}$ involves computing the difference between the costs under public and private ownership (both over the period since privatisation, and into the future). Costs under private ownership (to date) are based on actual data; and these also need to be projected into the future. However, the main difficulty lies in estimating what would have happened to costs under continued public ownership. In order to address this issue we need to build a counterfactual scenario based on historic and other economic data.

The efficiency savings due to liberalisation are calculated as the difference between the present value of actual (private) and counterfactual (continued public ownership) costs. Restructuring costs are then deducted, to arrive at the value of $\alpha \mathrm{W}$. The final step is to allocate $\alpha \mathrm{W}$ between the three groups (consumers, producers, and government), and therefore to determine the winners and losers (see below).

(a) Comparing Costs with and without Privatisation

The first task is to decide on the cut-off point between public and private ownership. In this paper we take 1996/97 as the first full year of privatisation ${ }^{13}$. However, the last year of public ownership is taken to be 1992/93, since this is the last year unaffected by the restructuring and privatisation programme $\mathrm{e}^{14}$ (see below). The transition period (1993/94 to 1995/96) saw the restructuring of the industry and its transfer to private ownership.

The sale of British Rail was accompanied by a radical restructuring of the industry, to create more than one hundred new companies. As a result, computing the total (actual) rail industry cost since privatisation is not straightforward, given the number of companies involved, and the complex set of financial payments flowing between the

\footnotetext{
${ }^{13}$ By 1996/97 the following parts of the industry had been sold: Railtrack (sold in May 1996); the three ROSCOs (sold in January/February 1996); thirteen infrastructure companies (sold between February and July 1996); six heavy maintenance depots (sold in April and June 1995); Red Star Parcels (sold in September 1995); the majority of the freight businesses (sold between December 1995 and May 1996, with the exception of Railfreight Distribution, which was not sold until November 1997). By the end of 1996/97, all of the 25 franchises had been let.

${ }^{14}$ In 1993/94 a voluntary severance offer was announced, in preparation for changes in organisation and ownership, which led to over 7000 employees leaving the industry.
} 
companies. In addition, care is required in comparing cost data before and after privatisation.

It was not possible to calculate the post-privatisation cost base by adding up the costs of the constituent parts (and eliminating inter-company flows), as the data did not permit such an analysis. We get around this problem by deriving industry costs as the difference between total industry revenue received from final users (train operator revenue), less total industry profits. The data are shown in Table 2, for the post-privatisation period (1996/97 to 1999/00). The data for earlier years are taken directly from BR Annual Reports.

The costs in Table 2 are operating costs (excluding depreciation). Whilst a full SCBA analysis would also include a consideration of the capital costs, this paper focuses only on the operating side of the business (and therefore assumes no significant capital substitution effects).

A number of points are worth noting with regard to the data in Table 2. First, it excludes the costs of minor (open-access) freight operators (though these are small), thus underestimating post-privatisation costs slightly. On the other hand, the profit data in Table 2 do not reflect the returns made by the many supplier companies sold as part of the restructuring, who now provide services to the industry (therefore overstating the post-privatisation costs). ORR costs are charged out to the industry, so do not need to be added separately.

The costs of the Strategic Rail Authority are included in Table 2 (netted off against TOC profits) - though to the extent that the SRA, and its predecessor, OPRAF, were staffed through transfers from other parts of government, the inclusion of these costs may overstate costs under the privatisation scenario, relative to the counterfactual. Indeed, Department of Transport costs, which would have been considerably higher under the counterfactual, are not included in our analysis.

Residual BR costs have been excluded (these include policing costs, which are charged out to the industry) $)^{15}$. On balance, given the scale of some of the supplier contracts - for example, Railtrack spends roughly $£ 1.3$ bn per year on contracts with infrastructure maintenance and renewal companies alone - we expect that the approach used overstates the post-privatisation costs overall, and therefore underestimates the efficiency gains from privatisation. For further explanation of the costs in Table 2 see Appendix A.

\footnotetext{
${ }^{15} \mathrm{BR}$ residual costs also include some property costs (non-operational) and costs relating to liabilities relating to the pre-privatisation period. Further analysis may look at whether any of these costs should be added to the post-privatisation cost base.
} 
TABLE 2

Rail Industry Costs

\begin{tabular}{|c|c|c|c|c|c|c|c|c|c|c|c|c|}
\hline $\begin{array}{l}\text { Rail Industry Costs } \\
£ \mathrm{~m}, 99 / 00 \text { prices }^{\mathrm{a}} \\
\end{array}$ & \multicolumn{5}{|c|}{ Pre-privatisation } & \multicolumn{3}{|c|}{ Transition $^{\mathrm{g}}$} & \multicolumn{4}{|c|}{ Post-privatisation } \\
\hline $\begin{array}{l}\text { Passenger revenue } \\
\text { Freight revenue }^{\mathrm{c}} \\
\text { Railtrack prop. Income }^{\mathrm{d}} \\
\text { Total industry revenue (A) }\end{array}$ & & & & & & & & & $\begin{array}{r}5,220 \\
607 \\
133 \\
\mathbf{5 , 9 6 0}\end{array}$ & $\begin{array}{r}5,223 \\
573 \\
134 \\
\mathbf{5 , 9 3 0}\end{array}$ & $\begin{array}{r}5,180 \\
555 \\
139 \\
\mathbf{5 , 8 7 4}\end{array}$ & $\begin{array}{r}5,150 \\
601 \\
137 \\
\mathbf{5 , 8 8 8}\end{array}$ \\
\hline Industry costs (A-B) & 4,287 & 4,195 & 4,176 & 4,394 & 4,406 & 4,023 & NA & $\mathbf{N A}$ & 4,316 & 4,070 & 4,093 & 4,155 \\
\hline Passenger train miles $(\mathrm{m})$ & 222 & 225 & 232 & 231 & 228 & 228 & 222 & 231 & 229 & 237 & 249 & 257 \\
\hline
\end{tabular}

(a) Conversion uses RPI data. (b) Includes subsidies. TOCs only (excludes Heathrow Express and Eurostar). Financial data for 5 TOCs were not available for 1999/00 - data were extrapolated for these TOCs. (c) Includes EWS and Freightliner16. (d) That part of Railtrack's income which does not come from TOCs or freight operators (needs to be included for comparability with BR data). (e) Profits before depreciation, net of SRA/OPRAF costs. (f) Weighted index used to calculate unit costs $(88 / 90=100)$. Weighted based on freight/passenger revenue. (g) It was not possible to construct comparable data for $94 / 95$ and $95 / 96$ due to restructuring.

Sources: BR Annual Reports; Annual Reports for individual companies (post privatisation). Transport Trends, 2001 Edition (DTLR).

${ }^{16}$ Data for Freightliner has been collected for 1998/99 and 1999/00 only - the data for 1996/97 and 1997/98 was extrapolated. 
For the counterfactual cost scenario, we have relied on historical data from BR's accounts. We started by reviewing the cost data for ten years prior to privatisation (1984/85 to 1993/94) - note that privatisation began in 1994/95 (eg. heavy maintenance depots were sold, and Railtrack was created as a separate company, within government). However, the final period chosen to inform the counterfactual was shortened to the five years $(1988 / 89$ to $1992 / 93)$ for the reasons outlined below.

$1993 / 94$ was excluded from the pre-privatisation period - this year was significantly affected by the privatisation and restructuring programme, and saw a voluntary severance programme, in preparation for privatisation, which led to a $7 \%$ reduction in headcount in that year ${ }^{17}$. The data from 1984/85 to $1987 / 88$ have also been excluded from the analysis. 1984/85 and 1985/86 was affected by the coal strike (see BR Annual Report, 1985/86).

The data between 1986/87 and 1988/89 were impacted by the sale of a number of businesses, continuing a trend which started in the early 1980s (see Table 1). In particular, BR sold British Rail Engineering Ltd (BREL) and Travellers Fare (station catering). Whilst it is not possible to calculate the exact impact of these sales on BR's cost base, the sales of the two businesses led to a reduction in headcount by around 13,000 (or $8 \%$ ) between 1987/88 and 1988/89.

Having established the appropriate time period for historical analysis, the counterfactual cost profile is then constructed based on the 1992/93 cost level, projected forward using an assumption about counterfactual efficiency gains (based on historical performance, and data from other industries). The construction of the counterfactual cost scenario is described in detail in Section IV.1.

The calculation of a counterfactual cost profile, based on historic data, raises the question of whether the pre and post-privatisation cost data are comparable. The formation of Railtrack in 1994/95 saw a change in accounting policy through the introduction of the Asset Maintenance Plan Charge (AMP). This approach forecasts the required repairs and renewal activity for track, route structures, stations and depots over a ten year period, and charges one tenth of this estimate to the P\&L in each year (as depreciation $^{18}$ ).

However, we are satisfied that the data (pre and post privatisation) remain comparable, despite the change in policy. The main impact of the change was to significantly increase overall costs (to address under-investment before privatisation, resulting from cash constraints), but this increase was reflected in a higher depreciation charge (which is excluded from operating costs in our analysis - see Appendix B). There is no evidence to suggest that the change resulted in any transfer of cost between operating costs and capex: the level of day-to-day infrastructure maintenance (the

\footnotetext{
17 1993/94 also saw a number of minor sell-offs (Transmark and Meldon Quarry).

${ }^{18}$ From 1998/99 onwards the AMP charge formally became part of depreciation under FRS 15.
} 
operating element of maintenance costs) increased in 1994/95, compared with the previous year $^{19}$.

To complete the analysis, the SCBA approach requires projections of both the actual (privatised) and counterfactual (public ownership) costs into the future. For simplicity, we have assumed that no further savings are made after 1999/00, and that the efficiency gap opened up by the private sector is closed over the following fifteen years (that is, the public sector is assumed to catch up over time).

(b) The Efficiency Gains from Restructuring and Privatisation

The value of efficiency gains from privatisation and restructuring are simply calculated as the difference between the present value of the two cost profiles $C_{g}-C_{p}$ less the present value of restructuring and privatisation costs $(\mathrm{R} \& \mathrm{P})$.

$\alpha ́ \mathrm{~W}=\mathrm{C}_{\mathrm{g}}-\mathrm{C}_{\mathrm{p}}-\mathrm{R} \& \mathrm{P}$

Restructuring and privatisation costs are assumed to be zero under the counterfactual scenario. Under the privatisation scenario they include all R\&P costs incurred within government (in 1993/94, 1994/95 and 1995/96), and all restructuring costs incurred since privatisation (1996/97 onwards, by the newly-privatised companies).

\section{(c) Distribution of the Net Efficiency Gains}

Once the present value of the net efficiency gains from privatisation has been calculated, the next step is to analyse its distribution between consumers, producers and government, as summarised in the following identity:

$\alpha^{\prime} \mathrm{W}=\dot{\alpha} \mathrm{Cust}+\alpha^{\mathrm{P}} \mathrm{rod}+\alpha_{\mathrm{G}} \mathrm{Gov}$

áCust is calculated as the difference between actual and counterfactual average revenue (price), multiplied by the actual volume. The price was computed using a composite volume index based on passenger miles and freight tonne-miles (weighted according to passenger and freight revenue). The counterfactual average revenue (price) projection was estimated by extrapolating the trend in average revenue for the five years prior to privatisation ${ }^{20}$.

The change in the government's position ( $\alpha \mathrm{Gov}$ ) is relatively complex, and includes a number of factors. First of all, by selling the industry the government foregoes any

\footnotetext{
${ }^{19}$ This is a key assumption, which could change the results significantly.
} 
potential profit/(deficit) streams from the business in future, and in return receives the sales proceeds for the industry and a share of future profitability through corporation tax. In contrast to earlier privatisations, the government has also continued to provide ongoing revenue subsidies ${ }^{21}$ to the sector since privatisation. The counterfactual scenario assumes that the government would continue to pay revenue subsidies to cover operating losses.

However, there is a further complication here. On privatisation, the government was relieved (to some extent ${ }^{22}$ ) of its responsibility to provide funding for capital investment (which averaged $£ 1.1$ bn per annum in 1999/00 prices during the five years prior to privatisation). Whilst the analysis in this paper focuses on operating costs (and ignores capital costs), it is necessary to reflect the saved capital costs in the calculation of the government's welfare position. The average of $£ 1.1 \mathrm{bn}$ per annum is used in the counterfactual to reflect this, and the same figure is used (with a negative sign) to reflect the capital costs which the private sector would need to cover out of operating profits ${ }^{23}$.

$\alpha ́$ Gov is therefore calculated as follows:

$$
\begin{aligned}
& \alpha ́ \text { Gov }=\text { Privatisation Scenario (Taxes }- \text { Subsidy }+ \text { Sales Proceeds) } \\
& -\quad \text { Counterfactual Scenario (Operating profits/losses + Capital Subsidies) }
\end{aligned}
$$

For producers, there is no counterfactual (since the counterfactual assumes public ownership). óProd is simply calculated as the post-tax profits under the privatisation scenario, less the amount paid to purchase the business (the corollary of government sales proceeds), less an amount to reflect capital expenditure (the corollary of the $£ 1.1$ bn saved capital cost used to calculate $\alpha$ Gov).

With regard to future projections - that is, beyond 1999/00 - it is assumed that the privatisation scenario variables remain at their $1999 / 00$ levels ${ }^{24}$, whilst the counterfactual cost and fares gradually fall until they are in line with the privatisation scenario. To

\footnotetext{
${ }^{20}$ For simplicity we are ignoring the allocative efficiency aspect of any price changes.

${ }^{21}$ In the analysis in Section IV, subsidies are taken to include both Central Government subsidies (paid through OPRAF), and PTE grants.

${ }^{22}$ Note that the Periodic Review (2000) allowed for significant grant payments direct to Railtrack (from 2001/02), to cover the exceptional level of renewal expenditure required over the next control period. However, grants to Railtrack in the years since privatisation (1996/97 to 1999/00) have been relatively small, and are not reflected in the allocation of efficiency gains between government and producers (however, grant income is taken account of in arriving at operating costs - see Appendix A).

${ }^{23}$ Thus implicitly assuming no savings on investment costs from privatisation.

${ }^{24}$ This means that the actual government subsidy and the saved capital cost is assumed to remain at its $1999 / 00$ level. Of course, existing franchise agreements build in further subsidy reductions, though it is not clear that these are sustainable. In addition, the debate over the levels of capital expenditure required, and particularly who will fund it, is ongoing.
} 
complete the above calculations, restructuring costs are subtracted from óGov and óProd, depending on when the costs were incurred (ie before or after privatisation).

\section{Results}

\section{Cost changes}

Figure 3 shows the profile of total rail industry costs (actual) over the period 1988/89 to $1999 / 00$. The data show that total costs were rising in the period up until 1992/93, fell sharply in 1993/94, as the restructuring of the industry began, and then remained broadly static in real terms between 1993/94 and 1999/00, whilst industry outputs grew strongly.

FIGURE 3

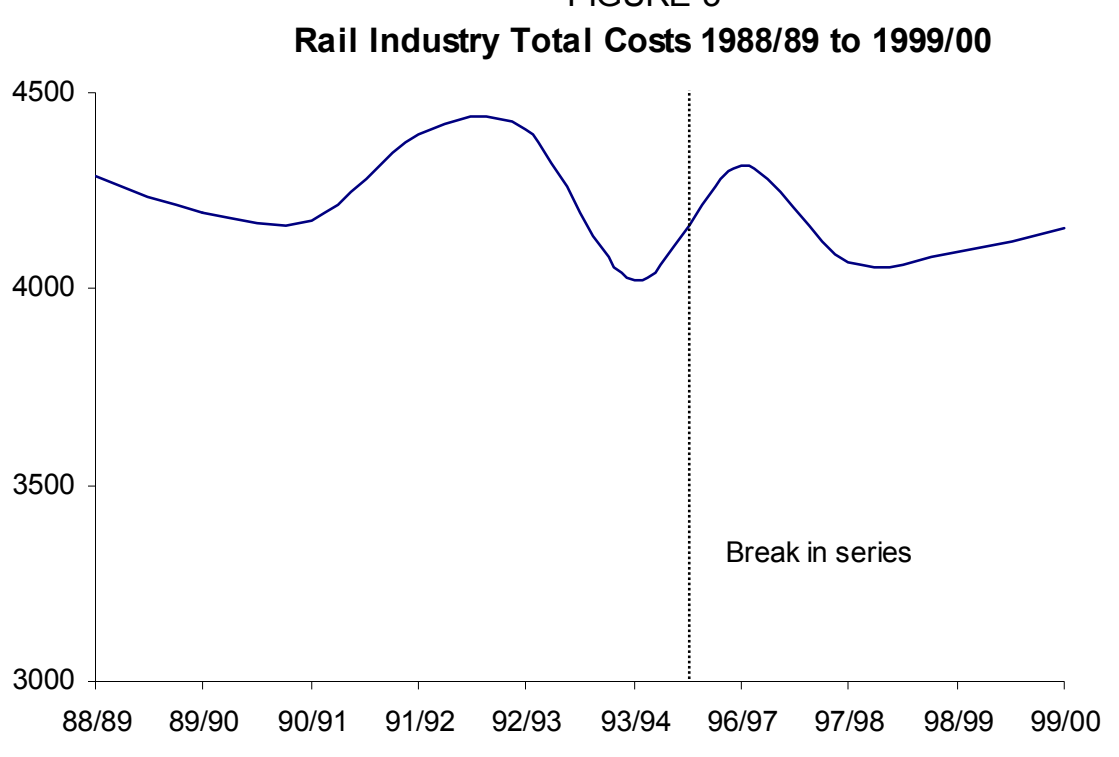

In order to understand what has been happening to unit costs over the period, we first need to decide on an appropriate measure of output. The next step is to separate out the impact of scale effects from underlying efficiency improvements. This second step requires an assumption about the proportions of fixed and variable costs in the rail industry. 
Our measure of output (see Table 2 above), is a composite index based on passenger train miles and freight tonne-miles, weighted according to the split between passenger and freight revenues. With respect to fixed and variable costs we make the following assumptions:

1. based on work carried out during the 2000 Periodic Review of Railtrack's access charges, we assume that $17 \%$ of infrastructure costs are variable with respect to volume (or $83 \%$ of costs are fixed). In our analysis, infrastructure costs make up $36 \%$ of the total cost base;

2. for the remainder of the cost base we assume that costs exhibit broadly constant returns to scale (we assume that $10 \%$ of these remaining costs are fixed).

Overall, our assumptions on scale mean that around $37 \%$ of the cost base is fixed with respect to volume ${ }^{26}$. Of course there will be other fixed costs, including infrastructure renewal and rolling stock depreciation costs, but these are excluded, as our analysis focuses on operating expenditure, and excludes capital (or depreciation) costs. The variable cost element is assumed to vary in line with our volume index, which is based on passenger train miles and freight tonne-miles.

It is important to note that passenger miles are not included in our measure of volume. This is a conservative assumption which reduces the level of efficiency gains attributed to privatisation in our calculations. Passenger miles have grown much faster than passenger train miles in recent years (21\%, compared to only 13\% since 1992/93). We note, however, that whilst train miles are likely to be the main driver of costs, some costs will increase in line with passenger miles (for example, an increased number of coaches have been employed since privatisation to accommodate higher passenger numbers; station and revenue-protection costs are also likely to vary with passenger miles).

Now that we have made our choice of volume measure and assumption about returns to scale, we are in a position to analyse the trends in unit costs (before and after privatisation), and to separate out the scale effects from underlying efficiency gains. Table 3 presents total and unit costs for the pre-privatisation period (1988/89 to 1992/93), splitting out the impact of scale effects from efficiency improvements.

Table 3 shows that scale effects would have caused unit costs to rise by $0.2 \%$ per annum over the five years 1988/89 to 1992/93 (falling volumes, with $37 \%$ of cost base

\footnotetext{
${ }^{25}$ The Periodic Review analysis found that $17 \%$ of maintenance and renewal cost was usage-driven. Since our analysis includes only maintenance costs, we have assumed that $17 \%$ of maintenance costs are variable. In addition, traction costs are also assumed to be variable, which (coincidentally) produces a figure of $17 \%$ variable costs overall.

${ }^{26}$ This assumption is in line with other studies of the rail industry. See Estache and Rus (2000), page 208.
} 
fixed). However, actual unit costs rose by $1.2 \%$ per annum, implying negative efficiencies, or an efficiency loss of $1 \%$ per annum over the period. However, in our central counterfactual scenario we assume that BR would have delivered efficiency gains of $1 \%$ per annum over the period 1992/93 to 1999/00. This assumption, which weighs in favour of public ownership, recognises some of the difficulties of comparing BR costs over the pre-privatisation period (changes in accounting policy ${ }^{27}$ ), and also reflects the experience of other regulated companies in the $\mathrm{UK}^{28}$.

TABLE 3

Pre-Privatisation Costs

\begin{tabular}{|c|c|c|c|c|c|c|}
\hline Pre-privatisation costs $-1999 / 00 £ \mathrm{~m}$ & $88 / 89$ & $89 / 90$ & $90 / 91$ & $91 / 92$ & $92 / 93$ & $\begin{array}{l}\text { Annual } \\
\text { Change }\end{array}$ \\
\hline $\begin{array}{l}\text { Scale effects (no efficiencies) } \\
\text { Fixed costs } \\
\text { Variable costs } \\
\text { Total costs }\end{array}$ & $\begin{array}{l}1,566 \\
2,721 \\
\mathbf{4 , 2 8 7}\end{array}$ & $\begin{array}{l}1,566 \\
2,693 \\
\mathbf{4 , 2 5 9}\end{array}$ & $\begin{array}{l}1,566 \\
2,721 \\
\mathbf{4 , 2 8 7}\end{array}$ & $\begin{array}{l}1,566 \\
2,691 \\
\mathbf{4 , 2 5 7}\end{array}$ & $\begin{array}{l}1,566 \\
2,672 \\
\mathbf{4 , 2 3 8}\end{array}$ & $\begin{array}{r}0 \% \\
(0.5 \%) \\
(0.3 \%)\end{array}$ \\
\hline $\begin{array}{l}\text { Actual costs } \\
\text { Total costs }\end{array}$ & 4,287 & 4,195 & 4,176 & 4,394 & 4,406 & $0.7 \%$ \\
\hline $\begin{array}{l}\text { Efficiency analysis } \\
\text { Composite volume index } \\
\text { Unit costs }^{\mathrm{a}} \text { - after scale effects } \\
\text { Unit costs - actual } \\
\text { Underlying efficiency gain/(loss) }\end{array}$ & $\begin{array}{r}100 \\
42.9 \\
42.9\end{array}$ & $\begin{array}{r}99 \\
43.0 \\
42.4\end{array}$ & $\begin{array}{r}100 \\
42.9 \\
41.8\end{array}$ & $\begin{array}{r}99 \\
43.0 \\
44.4\end{array}$ & $\begin{array}{r}98 \\
43.2 \\
44.9\end{array}$ & $\begin{array}{r}(0.5 \%) \\
0.2 \% \\
1.2 \% \\
(\mathbf{1 . 0 \% )}\end{array}$ \\
\hline
\end{tabular}

(a) Unit costs calculated by dividing total costs by the volume index.

Table 4 (below) shows actual and counterfactual costs (central scenario) for the postprivatisation period. The first section of the table shows the impact of scale effects on unit costs, given our assumptions about fixed and variable costs. The data show that total costs (after scale effects) are assumed to increase by $1.2 \%$ per annum, whilst the volume

\footnotetext{
${ }^{27}$ We note that BR made a significant change to its accounting policy in 1991/92, which meant that infrastructure costs were capitalised for the first time. Since BR produced data for 1991/92 on both accounting bases, we have been able to construct a consistent time series for the period 1988/89 to 1992/93. However, the lumpy nature of infrastructure spending may cause problems of comparability of individual years during the period before 1991/92 (though note that major upgrade expenditure was capitalised across the whole period).

${ }^{28}$ Domah and Pollitt (2001), page 126 - a 1\% annual efficiency improvement is considered a reasonable assumption of the likely sustainable improvement for the electricity industry. See also, Europe Economics (2000), page 18 - this report quotes a study by Bishop and Thomson (1992), which shows TFP growth in
} 
index grows by $1.9 \%$ p.a. over the same period, thus implying an elasticity of costs with respect to volume of 0.63 .

The second section of the table shows the actual trend in total and unit costs since privatisation - unit costs have fallen by $2.7 \%$ per annum over the period, of which $0.7 \%$ is due to scale effects, and $2.0 \%$ to underlying efficiency improvements. Finally, the third section of Table 4 shows counterfactual costs under the central scenario. This series is calculated by applying an efficiency saving of $1 \%$ per annum to total costs after scale effects in section 1 of the table. Under the counterfactual scenario, unit costs fall by $1.7 \%$ per annum, of which $1 \%$ per annum results from underlying efficiency savings, and the balance from scale effects $(0.7 \%)$.

TABLE 4

Post-Privatistion Costs

\begin{tabular}{|c|c|c|c|c|c|c|}
\hline $\begin{array}{l}\text { Post-privatisation costs - } \\
1999 / 00 £ \mathrm{~m}\end{array}$ & $92 / 93$ & $96 / 97$ & $97 / 98$ & $98 / 99$ & $99 / 00$ & $\begin{array}{l}\text { Annual } \\
\text { Change }\end{array}$ \\
\hline Scale effects (no efficiencies) & & & & & & \\
\hline Fixed costs ${ }^{\mathrm{a}}$ & 1,610 & 1,610 & 1,610 & 1,610 & 1,610 & $0 \%$ \\
\hline Variable costs & 2,796 & 2,784 & 2,938 & 3,073 & 3,190 & $1.9 \%$ \\
\hline Total costs & 4,406 & 4,394 & 4,548 & 4,683 & 4,800 & $1.2 \%$ \\
\hline Volume index & 98 & 98 & 103 & 108 & 112 & $1.9 \%$ \\
\hline Unit costs $^{\mathrm{b}}$ & 44.9 & 44.9 & 44.1 & 43.4 & 42.9 & $(0.7 \%)$ \\
\hline Actual costs & & & & & & \\
\hline Total costs & 4,406 & 4316 & 4070 & 4093 & 4155 & $(0.8 \%)$ \\
\hline Unit costs & 44.9 & 44.1 & 39.4 & 37.9 & 37.1 & $(2.7 \%)$ \\
\hline Underlying efficiency & & & & & & $2.0 \%$ \\
\hline Counterfactual costs & & & & & & \\
\hline Total costs & 4,407 & 4,222 & 4,325 & 4,409 & 4,474 & $0.2 \%$ \\
\hline Unit costs & 44.9 & 43.2 & 41.9 & 40.9 & 39.9 & $(1.7 \%)$ \\
\hline Underlying efficiency gain/(loss) & & & & & & $1.0 \%$ \\
\hline
\end{tabular}

(a) Fixed and variable costs recalculated in 1992/93.

(b) Unit costs calculated by dividing total costs by the volume index.

Figure 4 below shows actual costs, and the profile of counterfactual costs under three scenarios: pro-privatisation scenario (underlying efficiency gain of $0 \%$ per annum); central scenario (underlying efficiency gain of 1\% p.a., described above); and pro-public scenario (underlying efficiency gain of $2 \%$ p.a.).

the rail industry to be $1.2 \%$ per annum during the $1980 \mathrm{~s}$ (note, however, that TFP analyses need to be treated with care). 
As noted in Section III.2, it is assumed that the efficiency gap opened up by the private sector is gradually closed over the next 15 years (post 1999/00) - that is, the public sector is assumed to catch up. This assumption therefore weighs heavily in support of continued public ownership, and against privatisation.

FIGURE 4

Actual and Counterfactual Total Costs



\section{Calculation of efficiency gains}

Table 5 provides estimates of the discounted efficiency gains (pre-restructuring) resulting from rail privatisation in the UK. Estimates are shown for the three alternative assumptions about underlying efficiency improvements under the counterfactual scenario $(0 \%, 1 \%$ and $2 \%)$. In addition, the results are also shown for two different discount rates, $6 \%$ (used by government) and 10\% (private sector discount rate).

With a $6 \%$ discount rate, the central scenario shows the total discounted efficiency gains to be $£ 2.5 \mathrm{bn}$. This efficiency gain is partly offset by restructuring costs of $£ 1.4 \mathrm{bn}$ (see Table 6), yielding efficiency gains net of restructuring costs of $£ 1$. $1 \mathrm{bn}$. 
TABLE 5

Gross Efficiency Savings (Pre-Restructuring)

\begin{tabular}{lcc}
\hline $\begin{array}{l}\text { Counterfactual } \\
\text { unit cost reduction }\end{array}$ & \multicolumn{3}{c}{ Discount rate } \\
\hline $0 \%$ & $£ 5,200 \mathrm{~m}$ & $10 \%$ \\
$1 \%$ & $£ 2,500 \mathrm{~m}$ & $£ 4,800 \mathrm{~m}$ \\
$2 \%$ & $(£ 100 \mathrm{~m})$ & $£ 2,200 \mathrm{~m}$ \\
\hline
\end{tabular}

TABLE 6

Restructuring Costs

\begin{tabular}{l|rrrrrrr}
\hline $\begin{array}{l}\text { Restructuring costs } \\
\text { (present value) }\end{array}$ & $93 / 94$ & $94 / 95$ & $95 / 96$ & $96 / 97$ & $97 / 98$ & $98 / 99$ & $99 / 00$ \\
\hline $\begin{array}{l}\text { Government } \\
\text { Private sector }\end{array}$ & 427 & 415 & 239 & & & & \\
Total & $\mathbf{4 2 7}$ & $\mathbf{4 1 5}$ & $\mathbf{2 3 9}$ & $\mathbf{1 7 6}$ & $\mathbf{6 3}$ & $\mathbf{3 3}$ & $\mathbf{9 8}$ \\
\hline
\end{tabular}

Sources: British Rail Annual Reports; Annual Reports for privatised companies (Railtrack; 25 TOCs; 3 ROSCOs; EWS).

Table 7 (below) shows the profiling of the discounted savings between the period to date (1996/97 to 1999/00) and the future (the savings gap achieved to date is assumed to be closed over the next 15 years). The units of the data in Table 7 are £million (discounted).

Under the Central Scenario (6\% discount rate), the data show that privatisation has already yielded $£ 800 \mathrm{~m}$ in efficiency savings, although these savings have been more than offset by restructuring costs $(£ 1,400 \mathrm{~m})$. This position is unsurprising, as the industry has only been in private hands for four years, and we would expect the cost of restructuring to be recovered over a longer period. Total savings (including future savings ${ }^{29}$ ) under the Central Scenario amount to $£ 1,100 \mathrm{~m}$ ( $£ 500 \mathrm{~m}$ at a $10 \%$ discount rate) after restructuring costs.

The data in Table 7 are sensitive to the cost assumption under the counterfactual scenario. The savings estimates are much higher if we assume that underlying unit costs

\footnotetext{
${ }^{29}$ Note that, as described earlier, the future savings do not reflect additional savings - rather they are based on the continuation of the savings gap in 1999/00 into future years (though declining each year as the public sector is assumed to catch up).
} 
would have remained flat under public ownership (pro-privatisation scenario); on the other hand, under a counterfactual cost assumption of $2 \%$ (pro-public scenario), the savings become approximately zero (before restructuring costs) ${ }^{30}$. However, given the fact that unit costs increased during the pre-privatisation period (by more than would have been expected due to scale effects alone - see Table 3), it is difficult to argue for a counterfactual cost reduction that is more aggressive than assumed in the central scenario.

TABLE 7

Profiling of Efficiency Savings

\begin{tabular}{|c|c|c|c|c|c|c|}
\hline & \multicolumn{6}{|c|}{ Discount rate } \\
\hline & \multicolumn{3}{|c|}{$6 \%$} & \multicolumn{3}{|c|}{$10 \%$} \\
\hline & $\begin{array}{c}\text { To } \\
\text { date }\end{array}$ & Fut. & Total & To date & Fut. & Total \\
\hline \multicolumn{7}{|l|}{$\begin{array}{l}\text { Pro-privatisation } \\
\text { scenario }\end{array}$} \\
\hline Efficiency gains & 1,900 & 3,300 & 5,200 & 2,000 & 2,800 & 4,800 \\
\hline Restructuring costs & $(1,400)$ & - & $(1,400)$ & $(1,700)$ & - & $(1,700)$ \\
\hline Net efficiency gain/(loss) & 500 & - & 3,800 & 300 & - & 3,100 \\
\hline \multicolumn{7}{|l|}{ Central scenario } \\
\hline Efficiency gains & 800 & 1,700 & 2,500 & 800 & 1,400 & 2,200 \\
\hline Restructuring costs & $(1,400)$ & - & $(1,400)$ & $(1700)$ & - & $(1700)$ \\
\hline Net efficiency gain/(loss) & $(600)$ & - & 1,100 & $(900)$ & - & 500 \\
\hline \multicolumn{7}{|l|}{ Pro-public scenario } \\
\hline Efficiency gains & $(200)$ & 100 & $(100)$ & $(200)$ & 0 & $(200)$ \\
\hline Restructuring costs & $(1,400)$ & - & $(1,400)$ & $(1,700)$ & - & $(1,700)$ \\
\hline Net efficiency gain/(loss) & $(1,600)$ & - & $(1,500)$ & $(1,900)$ & - & $(1,900)$ \\
\hline
\end{tabular}

It is important to note that this paper does not seek to explain the improvements in efficiency. Freeman \& Shaw $(2000)^{31}$ provide some anecdotal evidence on efficiency improvements achieved by the TOCs (through staff reductions). In addition, during the 2000 Periodic Review Railtrack reported significant efficiency savings since privatisation (2.2\% per annum between 1994/95 and 1999/00) ${ }^{32}$. However, we note that a survey of rail transport efficiency carried out by Oum, Waters II and Chunyan (1999) found that

\footnotetext{
${ }^{30}$ Note that it is assumed that the public sector (counterfactual) cost profile catches up with the privatisation scenario over time, but that no restructuring costs are required to achieve this catch up. In practice, restructuring costs would also be required under public ownership.

${ }^{31}$ Op. cit. (Chapter 7).

${ }^{32}$ See Office of the Rail Regulator (December 1999).
} 
increased competition (driven by liberalisation and deregulation) led to improved efficiency in almost all of the papers reviewed ${ }^{33}$.

\section{Allocation of efficiency savings}

Table 8 shows the allocation of the efficiency gains/(losses) between producers, government and consumers. óGov/(óProd) include the privatisation proceeds /(payments). The subsidy data used in the analysis include both OPRAF subsidies and PTE grants. The units of the data in Table 8 are £million (discounted).

TABLE 8

Allocation of Efficiency Savings

\begin{tabular}{|c|c|c|}
\hline & \multicolumn{2}{|c|}{ Discount rate } \\
\hline & $6 \%$ & $10 \%$ \\
\hline & \multicolumn{2}{|c|}{ Pro-privatisation scenario (cost fall of $0 \%$ pa) } \\
\hline áGov & 2,400 & 3,900 \\
\hline óProd ${ }^{34}$ & 200 & $(2,000)$ \\
\hline óCust & 1,200 & 1,200 \\
\hline \multirow[t]{2}{*}{$\alpha ́ \mathrm{~W}$} & 3,800 & 3,100 \\
\hline & \multicolumn{2}{|c|}{ Central scenario (cost fall of $1 \%$ pa) } \\
\hline áGov & $(300)$ & 1,300 \\
\hline áProd & 200 & $(2,000)$ \\
\hline áCust & 1,200 & 1,200 \\
\hline \multirow[t]{2}{*}{$\alpha ́ \mathrm{~W}$} & 1,100 & 500 \\
\hline & \multicolumn{2}{|c|}{ Pro-public scenario (cost fall of $2 \%$ pa) } \\
\hline áGov & $(2,900)$ & $(1,100)$ \\
\hline áProd & 200 & $(2,000)$ \\
\hline áCust & 1,200 & 1,200 \\
\hline$\alpha ́ \mathrm{~W}$ & $(1,500)$ & $(1,900)$ \\
\hline
\end{tabular}

\footnotetext{
${ }^{33}$ We note that in the case of Britain's railways, competition between passenger train operators has been limited mainly to overlapping franchises and duplicate routes. However, the franchise process resulted in significant competition for franchises (competition for the market). In addition, some competition has developed in the freight business. Other elements of the value chain have also been subject to competition (at least in theory), for example, infrastructure maintenance companies, and ROSCOs.

${ }^{34}$ Note that changes in the counterfactual cost assumption only affect the payout to government: a better counterfactual cost performance means that the government would have had to provide lower support to the industry under public ownership, which means that its gains are lower the higher the counterfactual cost reduction. Consumer benefits (based on prices) and producer gains (based on actual, not counterfactual performance) are unaffected by changes in the counterfactual cost assumption
} 
The key result from Table 8 is that the consumer benefits from privatisation to the tune of $£ 1.2 \mathrm{bn}$. Average revenue (passenger and freight revenue divided by a composite volume index based on passenger miles and freight tonne-miles) was lower in real terms in every year since privatisation than before the sell-off (see Figure 5 below). This gain has been secured, in part, by the arrangements put in place to constrain price increases on regulated fares below the rate of inflation. Before privatisation, prices were often increased in real terms to choke off demand (the counterfactual assumes that this policy would have been continued).

FIGURE 5

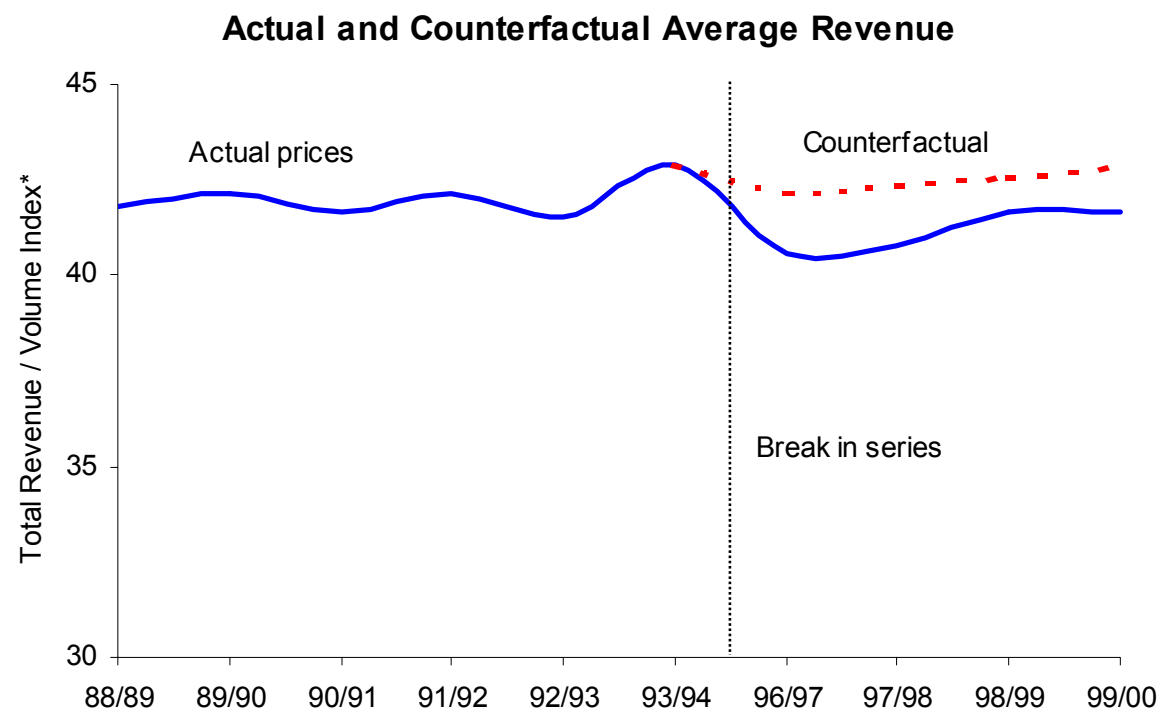

* Weighted index based on passenger miles and freight tonne-miles.

Overall, under the Central Scenario, consumers gain slightly more than the level of savings, leaving producers and government together with a loss of $£ 100 \mathrm{~m}$. The split between government and producers takes accounts of the privatisation sales proceeds ( $£ 7$ bn in present value terms - see Table 9 below). However, the split between the two groups is also highly sensitive to the assumption made about the government's savings through reduced capital investment (and correspondingly the level of private capital investment), which is not the focus of this paper. 
TABLE 9

Rail Privatisation Proceeds

\begin{tabular}{l|rr}
\hline Rail Privatisation proceeds & fbn (current prices) & £bn (present value) \\
\hline Railtrack * & 2.5 & 3.5 \\
ROSCOs & 1.7 & 2.4 \\
Freight & 0.3 & 0.4 \\
Infrastructure \& Maintenance cos. & 0.3 & 0.4 \\
BR Central Services & 0.2 & 0.3 \\
Total & $\mathbf{5 . 0}$ & $\mathbf{7 . 0}$ \\
\hline
\end{tabular}

* Includes $£ 596 \mathrm{~m}$ of debt.

Sources: NAO Reports (HC 576, Session 1997/98; HC 25 Session 1998/99); Public Enterprise Partnerships Team, HM Treasury.

\section{Output quality}

Whilst privatisation may have resulted in significant efficiency savings, a key question is what has happened to output quality. There are four key measures of output quality which should be considered: train performance (delays); train crowding; asset condition (broken rails; track quality) and safety.

To date the industry's performance in these areas has been strongly criticised from many directions, particularly in the aftermath of Hatfield - and privatisation, with its focus on contractual regimes between disparate industry players, and the need to provide a return for shareholders, has often been blamed. However, looking at the pre-Hatfield data, it is far from clear that continued government ownership (the counterfactual) would have produced better results. Below we look at the four measures in turn.

\section{(a) Train performance}

Train performance (delay per passenger train) has improved significantly since privatisation (pre-Hatfield - see Figure 6 below). Performance improved sharply in the first year after privatisation (due to improvements by Railtrack), but then deteriorated steadily over the next three years (due to worsening train operator performance), before improving again in 1999/00. Overall, delays per passenger train in 1999/00 were down $16 \%$ compared to 1995/96. The performance regimes which exist between Railtrack and the TOCs, and between the TOCs and OPRAF/SRA, provide rewards/penalties for 
performance above/below target. These regimes have focused management attention on the issue of performance.

FIGURE 6

Delay per passenger train

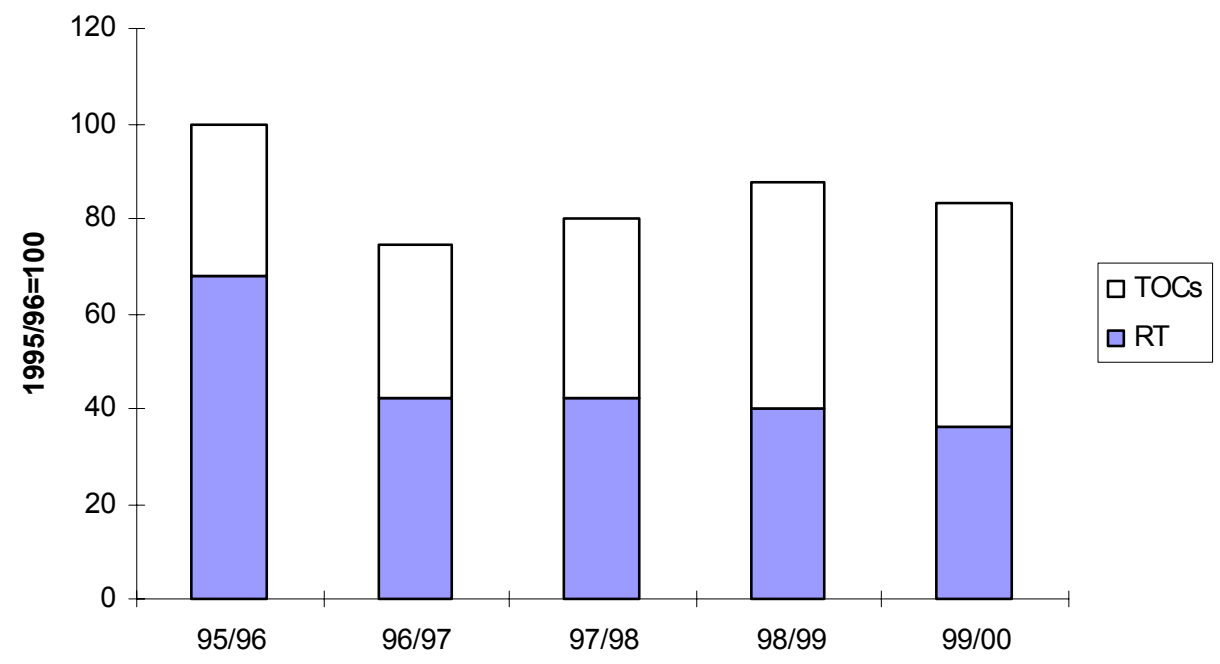

Source: Railtrack.

The key question is what would have happened to performance under public ownership, given the sharp volume growth we have seen in recent years. Of course, it is impossible to know for sure, though we note the absence of performance regimes under the old structure. However, we can gain some insight by comparing the changes in train performance and volume growth between 1995/96 and 1999/00 (under a privatised structure), with a comparable five year period of volume growth during the boom of the mid-to-late 1980s (under the old BR structure).

Table 10 shows that, since privatisation, train performance (measured by punctuality) has improved by $2.7 \%$. This improvement was achieved against a background of growth in passenger miles and passenger train miles of $28 \%$ and $11 \%$ respectively over the period. During a comparable period in the 1980s (1984/85 to 1988/89) ${ }^{35}$, which saw lower volume growth, performance actually deteriorated (see Table 11). Even if we strip out the sharp improvement in performance achieved in the first year of the newly privatised structure (1996/97), the deterioration since then only amounts to $0.6 \%$, compared to $1 \%{ }^{36}$ during the period of BR control in the mid $1980 \mathrm{~s}$ - whilst volume growth has been much greater.

\footnotetext{
${ }^{35}$ This period saw sharp growth passenger miles, train miles and freight tonne-miles. 1988/89 is taken as the cut-off point, as passenger miles started to deteriorate after that date.

${ }^{36}$ Though note that the BR data is not quoted to 1 decimal place.
} 
It therefore seems unlikely that train performance would have been better under public ownership; indeed, the evidence suggests that it may have been considerably worse.

TABLE 10

Train Performance and Volume: Post-Privatisation

\begin{tabular}{l|rrrrrr}
\hline Performance & $95 / 96$ & $96 / 97$ & $97 / 98$ & $98 / 99$ & $99 / 00$ & Change \\
& & & & & & \\
\hline Punctuality $^{\mathrm{a}}$ & $89.5 \%$ & $92.5 \%$ & $92.5 \%$ & $91.5 \%$ & $91.9 \%$ & $+2.7 \%$ \\
Pass. Train miles (m) & 231 & 229 & 237 & 249 & 257 & $+11 \%$ \\
Pass. Miles (bn) & 18.6 & 19.9 & 21.6 & 22.6 & 23.8 & $+28 \%$ \\
\hline
\end{tabular}

(a) Percentage of trains on time.

Sources: National Rail Trends 2000/01, Q2; Transport Trends, 2001 Edition (DTLR).

OPRAF Annual Reports (1996/97 to 1999/00).

TABLE 11

Train Performance and Volume: BR Regime

\begin{tabular}{l|rrrrrr}
\hline Performance & $84 / 85$ & $85 / 86$ & $86 / 87$ & $87 / 88$ & $88 / 89$ & Change \\
\hline Punctuality $^{\mathrm{a}}$ & $90 \%$ & $89 \%$ & $90 \%$ & $90 \%$ & $89 \%$ & $(1 \%)$ \\
Pass. Train miles (m) & 202 & 201 & 203 & 213 & 222 & $+10 \%$ \\
Pass. Miles (bn) & 18.5 & 18.9 & 19.2 & 20.1 & 21.3 & $+15 \%$ \\
\hline
\end{tabular}

(a) Percentage of trains on time.

Sources: BR Annual Reports 1985/86 to 1989/90. Transport Trends, 2001 Edition (DTLR).

(b) Train overcrowding

Meanwhile, train overcrowding (commuter services) has got worse, with four of the ten train operators serving the London market experiencing excessive overcrowding in $1999 / 00^{37}$. It is clear that overcrowding would also have worsened considerably under continued government ownership, given the unprecedented passenger growth we have seen (which is assumed to be exogenous in this paper).

(c) Asset condition

The data show that asset condition on the network has deteriorated since privatisation. The number of broken rails started to increase in the mid-1990s from a long-run average

${ }^{37}$ SRA Annual Report, 1999/00. 
of between 600 and 700, to 949 in $1999 / 00^{38}$. The Regulator has argued that Railtrack's investment in track maintenance and renewal - though greater than envisaged when the company's charges were set at privatisation - was insufficient, given the level of traffic growth. Railtrack inherited a network which had suffered from underinvestment for many years. It is therefore unclear whether extra money for investment would have been forthcoming under government ownership. The arguments on asset condition are largely concerned with capital investment levels, and do not affect our analysis of operating costs.

(d) Safety

Finally, concerns over safety have increased since privatisation. However, the data on accidents do not show any statistically significant change since privatisation, as noted in the Health \& Safety Commission “Cullen” report (2001) - written post-Hatfield:

"The statistics do not bear out a picture of a declining safety trend. Professor $A W$ Evans, Professor of Transport Safety at the Centre for Transport Studies at University College London, had made an extensive statistical analysis of the safety performance of the railways before and after privatisation. He concluded that safety performance was the same before and after privatisation".

(e) Overall output quality

To sum up, looking at the data prior to Hatfield the balance of evidence suggests that output quality is actually higher under the privatisation scenario. Of course train performance has deteriorated sharply since the Hatfield disaster, as Railtrack responded by closing large parts of the network. The Regulator has argued that the large-scale closure programme was caused by the lack of an adequate asset register (and therefore knowledge of the condition of the company's assets) ${ }^{39}$. However, the closure programme also reflects a lower risk tolerance since privatisation. This reduction has a value, though is difficult to quantify. Perhaps BR would not have taken the course adopted by Railtrack, but passengers may have faced a higher risk as a result.

\footnotetext{
${ }^{38}$ Track quality also deteriorated from the mid 1990s to 1997, though has been improving since then. Sources: HM Rail Inspectorate; Railtrack.

${ }^{39}$ Much of the data on asset condition was transferred from Railtrack to the infrastructure maintenance and renewal companies on privatisation.
} 


\section{Conclusions}

In the aftermath of the government's decision (October 2001) - to place Railtrack into administration - attention has focused on what went wrong with privatisation, and how crucial network investment will be financed in future. Against this background, our aim has been to evaluate the operating cost efficiency gains (or losses) resulting from privatisation and restructuring, using a social cost-benefit analysis framework. The actual data used in our analysis cover the period to (financial year) 1999/00, and therefore stops short of the Hatfield disaster. The next financial year (2000/01), which includes Hatfield, is not representative of the period since privatisation as a whole (and not all of the financial data are available in any case). We conclude that:

1. Industry outputs have risen sharply since privatisation (1992/93 to 1999/00). Passenger train miles, passenger miles and freight tonne miles have grown by $13 \%$, $21 \%$ and $19 \%$ respectively. At the same time, the cost base has been reduced by $6 \%$ in real terms. As a result, unit costs have fallen sharply over the period, by $17 \%$ (or $2.7 \%$ per annum). After taking account of scale effects, the rail industry has achieved efficiency savings of $13 \%$ (or $2 \%$ per annum) since privatisation.

2. The post-privatisation performance on efficiency has been significantly better than that achieved under public ownership. During the five years prior to privatisation, unit costs went up by approximately $1 \%$ per annum (after stripping out the impact of scale effects). However, for our central scenario, we have assumed counterfactual efficiency savings of $1 \%$ per annum (based on other UK privatised industries).

3. In the central scenario, privatisation and restructuring has generated efficiency savings to date of about $£ 800 \mathrm{~m}$, compared to the counterfactual of continued public ownership. The savings, achieved over only four years, are more than offset by restructuring costs. However, assuming that the savings achieved to date are rolled forward into the future (though declining to zero over 15 years as the public sector catches up), the total savings rise to $£ 2.5 \mathrm{bn}$ under the central scenario (prerestructuring), or $£ 1.1 \mathrm{bn}$ after restructuring costs. We note that the savings reported here are sensitive to the counterfactual cost assumption ${ }^{40}$.

\footnotetext{
${ }^{40}$ The results are also sensitive to the assumptions concerning the level of fixed costs in the industry, though we consider that we have built in sufficient scale economies into our calculation.
} 
4. Consumers have benefited considerably from privatisation ( $£ 1.2 \mathrm{bn})$ - indeed by more than the level of savings. Table 8 shows that, as a result, producers and government together lose $£ 100 \mathrm{~m}$, with the government losing $£ 300 \mathrm{~m}$, whilst producers gain $£ 200 \mathrm{~m}$.

5. Output quality has improved since privatisation (pre-Hatfield). Train performance has improved significantly, whilst the evidence from the 1980s suggests that it would have deteriorated under the old BR structure. Although overcrowding has got worse, we argue that the same would have happened under public ownership, given the level of passenger growth. The increase in the number of broken rails has also resulted from increased traffic growth; however, it is unclear whether extra money would have been forthcoming to address this issue in the public sector. Finally, despite concerns over safety, the Cullen report - written after the Hatfield disaster - found safety performance to be (statistically) the same before and after privatisation.

Of course, post-Hatfield, train performance has worsened dramatically. This position has resulted partly from the lack of an adequate asset register, which led Railtrack to close down large parts of the network. However, it also reflects a reduction in risk tolerance since privatisation. Whilst British Rail may not have taken the same action as Railtrack, passengers may have been subjected to higher risk as a result. The value of this reduced risk is often ignored and is difficult to quantify.

Looking forward, the Periodic Review (2000) envisaged a significant increase in investment in the network, to deliver improved safety systems, and better performance. There have also been suggestions that long-term costs may have risen in the aftermath of Hatfield. However, these cost increases largely affect capital, not operating costs. Furthermore, the Periodic Review also committed Railtrack to deliver significant efficiency savings in the coming years.

The achievement of further efficiencies in the future will be key to delivering the government's objective to improve rail services. This paper finds that a privatised structure, where shareholders demand a return on their investment, has led to significant improvements in operating efficiency - it remains to be seen whether the new regime, with a not-for-profit infrastructure owner, will deliver the same efficiency improvements. 


\section{APPENDIX A \\ CALCULATION OF INDUSTRY COSTS}

\begin{tabular}{|c|}
\hline Costs before pri \\
\hline $\begin{array}{l}\text { For the period prior to privatisation, industry operating costs are taken direct from the BR } \\
\text { accounts: } \\
\text { - The starting point for determining industry costs is BR's operating costs before } \\
\text { exceptional items (the latter includes restructuring and severance costs - these are } \\
\text { included separately in our analysis within R\&P costs). } \\
\text { - Depreciation is subtracted, to obtain operating costs before depreciation; } \\
\text { - The amortisation of deferred grant income (ie. the amount of capital grant released } \\
\text { to the P\&L to cover depreciation costs), which appears as a negative cost, is also } \\
\text { taken out (therefore increasing costs to their true level). } \\
\text { EU and level crossing grants are added back (again, these appear as negative costs). } \\
\text { Note that Channel Tunnel costs were capitalised, and therefore had no impact on } \\
\text { operating costs. However the pre-privatisation data do contain some costs in } \\
\text { respect of Union Railways (planning costs for the high-speed rail link between } \\
\text { London and the Channel Tunnel). These costs have not been stripped out since we } \\
\text { expect that similar costs are currently being incurred on large projects (for example, } \\
\text { WCML) and are being absorbed within operating costs in the post-privatisation } \\
\text { data. }\end{array}$ \\
\hline
\end{tabular}


Costs after privatisation (1996/97 onwards)

For the period after privatisation, costs are calculated as follows:

- Total industry profits (pre-depreciation) are subtracted from total final revenue from customers/funders.

- Total final revenue is derived by adding the revenues (including subsidy) for all 25 TOCs, plus the two largest freight operators, EWS and Freightliner. In addition, other Railtrack revenue is also added (this is property income, which would have previously been received by BR. It also includes a small amount of grant income). Open-access revenue (Channel Tunnel and Heathrow Express) is excluded (did not exist under BR - and is not included in the volume data used to calculate unit costs).

- Industry profits are taken as the sum of TOC, freight operator, ROSCO and Railtrack profits. The profit data exclude depreciation and also exceptional items (restructuring). As for the BR data, any grants included as negative costs are added back.

- As noted in the main report, the profit data do not take account of the profits made by the many supplier companies providing services to the industry (particularly the infrastructure maintenance and renewal companies). To this extent, postprivatisation costs are over-estimated, and therefore savings underestimated. However, the post-privatisation data exclude the costs of minor freight operators. The costs of the Strategic Rail Authority are included. Residual BR costs have not been added to the post-privatisation costs (see section III.2 above).

- The Railtrack Asset Maintenance Plan (AMP) charge is treated as depreciation (this treatment was formally adopted by the company in 1997/98). 


\section{APPENDIX B COMPARING PRE- AND POST-PRIVATISATION DATA}

The following table compares the cost base in 1993/94 with 1994/95, following the creation of Railtrack. During this year, it is often reported that the revenue subsidy doubled - and this fact is used to discredit the privatisation process. However, the cost (before depreciation) increased by only $1.6 \%$ in nominal terms (and actually fell in real terms). The step change in subsidy in 1994/95 can be explained largely by two factors:

1. in preparation for privatisation, the financial flows were restructured to allow each element of the business to earn a commercial return (the government captured these returns through sales proceeds); and

2. on its formation in 1994/95, Railtrack introduced a new method of accounting ${ }^{41}$ for maintenance and renewals expenditure, in line with other regulated industries (e.g. . BAA and Water Companies) ${ }^{42}$.

${ }^{41}$ Asset Plan Maintenance (AMP). See Railtrack Annual Reports.

${ }^{42}$ See Bradshaw \& Lawton-Smith (2000), page 114-115. Previously, BR had accounted for this cost on a "pay-as-you-go" basis (and the investment in maintenance and renewal had been insufficient to maintain the network in steady-state in the years prior to privatisation). 


\begin{tabular}{|c|c|c|c|c|c|}
\hline \multirow{2}{*}{$\begin{array}{l}\text { Industry Costs } \\
\text { (£m current prices) }\end{array}$} & \multirow[t]{2}{*}{$1993 / 94$} & \multicolumn{4}{|c|}{$1994 / 95$} \\
\hline & & BR & Railtrack & Consol. & Total \\
\hline Staff costs & 2,493 & 2,149 & 287 & - & 2,436 \\
\hline Materials, supplies/services & 1,119 & 1,157 & 5 & - & 1,162 \\
\hline Other external charges & - & - & 1,215 & $(1,238)$ & $(23)$ \\
\hline Own work capitalised $^{\mathrm{a}}$ & $(253)$ & $(22)$ & (61) & - & (83) \\
\hline Access charges & - & 2169 & - & $(2,169)$ & - \\
\hline Other $^{\mathrm{b}}$ & 50 & 19 & (46) & - & $(27)$ \\
\hline Total before depreciation & 3,409 & 5,472 & 1,400 & $(3,407)$ & 3,465 \\
\hline Depreciation (inc. AMP) & 292 & 169 & 576 & - & 745 \\
\hline Amortisation of grant income & $(192)$ & $(91)$ & - & - & $(91)$ \\
\hline Total cost & 3,509 & $\mathbf{5 , 5 5 0}$ & 1,976 & $(3,407)$ & 4,119 \\
\hline
\end{tabular}

(a) Includes other operating income

(b) Includes other adjustments to reflect grants included as negative income, and stripping out of privatisation costs within Railtrack.

Sources: British Rail Annual Reports, 1993/94 and 1994/95; Railtrack Annual Report 1994/95.

The table also shows that the increase in cost (and hence subsidy) was driven by a rise in depreciation resulting from a change in accounting policy as explained above. Since other (non-depreciation) costs remained broadly the same, there is no evidence to suggest that the change in accounting policy led to any transfer of costs between operating and capital expenditure. 


\section{APPENDIX C \\ KEY ASSUM[PPTIONS OF THE SOCIAL COST BENEFIT ANALYSIS}

The key assumptions are summarised in this appendix.

\begin{tabular}{|c|c|c|c|}
\hline & \multicolumn{2}{|c|}{ Period to date (to $1999 / 00$ ) } & \multirow[t]{2}{*}{ Projections (15 years) } \\
\hline & $\begin{array}{l}\text { Privatisation } \\
\text { (actual) }\end{array}$ & $\begin{array}{l}\text { Public ownership } \\
\text { (counterfactual) }\end{array}$ & \\
\hline Operating costs & See Appendix A & $\begin{array}{l}1992 / 93 \text { cost base } \\
\text { projected forward based } \\
\text { on assumptions } \\
\text { concerning scale effects, } \\
\text { and three different } \\
\text { scenarios for underlying } \\
\text { efficiency gains. }\end{array}$ & $\begin{array}{l}\text { The efficiency gap } \\
\text { opened up by the } \\
\text { privatisation scenario is } \\
\text { assumed to be closed in } \\
\text { a linear fashion over the } \\
\text { next } 15 \text { years. }\end{array}$ \\
\hline Restructuring costs & $\begin{array}{l}\text { All restructuring costs } \\
\text { included from 1993/94 to } \\
1999 / 00 \text { (both costs } \\
\text { incurred by BR, and } \\
\text { privatised companies). }\end{array}$ & None & $\begin{array}{l}\text { No further restructuring } \\
\text { costs assumed in the } \\
\text { projections. }\end{array}$ \\
\hline Prices & $\begin{array}{l}\text { Calculated as total TOC } \\
\text { and Freight operator } \\
\text { revenue divided by a } \\
\text { composite volume index, } \\
\text { based on passenger miles } \\
\text { and freight tonne-miles. }\end{array}$ & $\begin{array}{l}\text { Price trends calculated } \\
\text { from BR revenue and } \\
\text { volume data are } \\
\text { extrapolated forward } \\
\text { from the } 1993 / 94 \text { base } \\
\text { to } 1999 / 00 \text {. }\end{array}$ & $\begin{array}{l}\text { The price advantage (ie } \\
\text { lower prices) generated } \\
\text { by the privatisation } \\
\text { scenario is assumed to } \\
\text { be closed in a linear } \\
\text { fashion over } 15 \text { years. }\end{array}$ \\
\hline Subsidies & $\begin{array}{l}\text { Actual data taken from } \\
\text { National Rail Trends } \\
\text { (2000/01, Q2), SRA. }\end{array}$ & $\begin{array}{l}\text { Assumes that the } \\
\text { government would pay } \\
\text { revenue subsidies equal } \\
\text { to operating losses. Also } \\
\text { assumes that the } \\
\text { government would } \\
\text { continue to cover capital } \\
\text { costs (see below), at the } \\
\text { average level over the } 5 \\
\text { years before } \\
\text { privatisation ( } £ 1.1 \text { bn per } \\
\text { annum). }\end{array}$ & $\begin{array}{l}\text { Actual scenario } \\
\text { continues at the } 1999 / 00 \\
\text { level. The counterfactual } \\
\text { level of revenue } \\
\text { subsidies gradually } \\
\text { changes as cost } \\
\text { efficiencies and price } \\
\text { reductions feed through } \\
\text { over } 15 \text { years (see } \\
\text { above). }\end{array}$ \\
\hline Capital costs & \multicolumn{2}{|c|}{$\begin{array}{l}\text { Ignored in the analysis, except in calculating the } \\
\text { change in welfare between government and } \\
\text { producers. Since the counterfactual assumes that the } \\
\text { government would have continued to invest } £ 1.1 \mathrm{bn} \\
\text { per annum to fund capital costs, we assume that the } \\
\text { private sector would also need to provide this same } \\
\text { amount of funding under the privatisation scenario } \\
\text { (no capital savings assumed). }\end{array}$} & $\begin{array}{l}\text { Continues at } 1999 / 00 \\
\text { levels for fifteen years. }\end{array}$ \\
\hline Volumes & $\begin{array}{l}\text { Actual data taken from } \\
\text { National Rail Trends } \\
\text { (2000/01, Q2), SRA. }\end{array}$ & $\begin{array}{l}\text { Volume growth } \\
\text { assumed to be same as } \\
\text { for the privatisation } \\
\text { scenario. }\end{array}$ & $\begin{array}{l}\text { No further volume } \\
\text { growth assumed. }\end{array}$ \\
\hline
\end{tabular}




\section{REFERENCES}

Beeching (1963), The Reshaping of British Railways, British Railway Board, London, HMSO.

Beeching (1965), The development of the major railway trunk routes, British Railway Board, Great Britain, Waterlow \& Sons Limited.

Bishop and Thompson (1992), 'Regulatory Reform and Productivity Growth in the UK's Public Utilities', Applied Economics, vol 24, pp. 1181-90.

Bradshaw and Lawton-Smith (2000), Privatisation and Deregulation of Transport, Basingstoke, Macmillan.

Burns and Weyman-Jones (1994), 'Regulatory Incentives, Privatisation and Productivity Growth in UK Electricity Distribution', CRI Technical Paper no. 1, London: CIPFA.

Chisari, Estache and Romero (1999), 'Winners and Losers from the Privatisation and Regulation of Utilities: Lessons from a General Equilibrium model of Argentina', World Bank Economic Review, vol. 13, pp. 357-78.

Department of Transport (1992), New Opportunities for the Railways: the privatisation of British Rail, Cmnd 2012, London, HMSO.

Domah and Pollitt (2001), 'The Restructuring and Privatisation of Electricity Distribution and Supply Businesses in England and Wales: A Social Cost-Benefit Analysis', Fiscal Studies (2001) vol. 22, no. 1, pp 107-146.

Estache and De Rus (2000), Privatization and Regulation of Transport Infrastructure: Guidelines for Policymakers and Regulators, The World Bank, Washington.

Europe Economics (2000), Review of Railtrack Efficiency: A Report for the Office of the Rail Regulator, London.

Freeman and Shaw (2000), All Change: British Railway Privatisation, London, McGrawHill.

Galal et al (1994), Welfare Consequences of Selling Public Enterprises: An Empirical Analysis, Oxford, Oxford University Press.

Health \& Safety Commission (2001), The Ladbroke Grove Rail Inquiry: Part 2 Report, Norwich, HMSO.

Jones, Tandon and Vogelsang (1990), Selling Public Enterprises: A Cost-Benefit Methodology, Cambridge, Massachusetts, MIT Press.

Kain (1998), 'The Reform of Rail Transport in Great Britain', Journal of Transport Economics \& Policy, vol. 32, part 2.

Martin and Parker (1997), The Impact of Privatisation: Ownership and Corporate Performance in the UK, London, Routledge.

NAO (1998), The Flotation of Railtrack, HC 25 Session 1998-99, DETR, London, The Stationary Office. 
NAO (1998), The Privatisation of the Rolling Stock Leasing Companies, HC 576 Session 1997-98, DETR, London, The Stationary Office.

NAO (1999), The Sale of Railfreight Distribution, HC 280 1998/99 Session, DETR, London, The Stationary Office.

Newbery \& Pollitt (1997), 'The Restructuring and Privatisation of Britain's CEGB: was it worth it?', Journal of Industrial Economics, vol. 45, pp. 269-303.

Office of the Rail Regulator (December 1999), The Periodic Review of Railtrack's Access Charges: Provisional Conclusions on Revenue Requirements, London.

Oum, Waters II, and Chunyan (1999), Journal of Transport Economics and Policy, vol. 33, Part I, pp. 9-42.

Pollitt (1997), 'The impact of Liberalisation on the Performance of the Electricity Supply Industry: an International Survey', Journal of Energy Literature, vol 3, no. 2, pp. 3-31.

Strategic Rail Authority (2000), 1999/00 Annual report, London. Yarrow (1992), 'British Electricity Prices Since Privatisation', Oxford, Regulatory Policy Institute, Studies in Regulation, paper number 1.

Company Accounts and Reports

Angel Trains

British Railways Board

English, Welsh and Scottish Railways ${ }^{43}$

Eversholt

Porterbrook

Railtrack

Train Operating Companies ${ }^{44}$
$1996 / 97$ to $1999 / 00$

$1985 / 86$ to $1995 / 96$

$1996 / 97$ to $1999 / 00$

$1996 / 97$ to $1998 / 99$

$1996 / 97$ to $1999 / 00$

$1994 / 95$ to $1999 / 00$

$1996 / 97$ to $1999 / 00$

\footnotetext{
${ }^{43}$ Note that data for Freightliner taken from the company's web site (for 1998/99 and 1999/00 only).

${ }^{44}$ As noted in the notes to Table 2, data for some TOCs is not available for 1999/00.
} 